\title{
ANALISIS CAPACITY CONSTRAINED WORKER DENGAN PENDEKATAN WAKTU BAKU, DENYUT JANTUNG DAN PROFILE OF MOOD STATES (STUDI KASUS PADA INDUSTRI TEMPE "MUCHLAR"KASIHAN BANTUL)
}

\author{
Analysis of Capacity Constrained Worker Using Time Study, Heart Rate and Profile of Mood States \\ (Case Study of Tempe Industry "Muchlar" Kasihan Bantul)
}

Maman Zuriwiatma, Mirwan Ushada, Guntarti Tatik Mulyati

Jurusan Teknologi Industri Pertanian, Fakultas Teknologi Pertanian, Universitas Gadjah Mada,

Jl. Flora No. 1, Bulaksumur, Yogyakarta 55281

Email: mirwan@tip-ugm.org

\begin{abstract}
ABSTRAK
Tempe "Muchlar" merupakan salah satu industri pangan yang semua pekerjaannya dilakukan manual sehingga proses produksinya sangat tergantung kapasitas dari pekerja. Permasalahan muncul karena target produksi tempe setengah jadi sebesar $\pm 3.600 \mathrm{~kg}$ tidak tercapai. Penelitian ini bertujuan untuk mengidentifikasi Capacity Constrained Worker yang terjadi menggunakan pendekatan waktu baku, denyut jantung, profile of mood states serta menentukan perbaikan yang tepat untuk dapat meningkatkan kapasitasnya. Hasil pengukuran terhadap pekerja dikonfirmasi dengan analisis keadaan lingkungan kerja. Dari hasil penelitian dapat ditentukan bahwa pekerja yang menjadi Capacity Constrained Worker adalah pekerja stasiun pemisahan kulit. Hal ini dibuktikan dari waktu baku yang diperoleh sebesar 5,63 detik/ $\mathrm{kg}$ yang membuat target produksi sebesar $3.600 \mathrm{~kg}$ dalam 5 jam tidak tercapai. Dengan perbaikan yang dilakukan yaitu menurunkan suhu ruangan dari tinggi ke normal waktu baku pekerja dapat meningkat menjadi 5 detik $/ \mathrm{kg}$ dan target produksi dapat tercapai serta meningkatkan pendapatan. Perbaikan dengan menerapkan buffer management dapat mengurangi stasiun kerja yang menjadi constraint.
\end{abstract}

Kata kunci: Waktu baku, Capacity Constrained Worker, target produksi

\begin{abstract}
Tempe "Muchlar" is one the potential food indutry which all the job is pursued manually. The production process is based on the worker capacity. The main problem is the industry could not fulfill the production target of half-finished Tempe product of $\pm 3.600 \mathrm{~kg}$. The research objective is to identify Capacity Constrained Worker using standard time, heart rate, profile of mood states and recommending the improvement to increase the worker capacity. The measurement results were confirmed using analysis of working environment. The research results indicated that Capacity Constrained Worker of Tempe Industry was the worker of peeling. It was indicated by the standard time of $5,63 \mathrm{detik} / \mathrm{kg}$ that could not fulfill the production target of $3.600 \mathrm{~kg}$ in 5 work hours. The improvement was pursued by decreasing the room temperature of working station. The improvement could increase the standard time of $5 \mathrm{~second} / \mathrm{kg}$, fulfilling the production target and increasing the income. Finally the improvement using Buffer Management could improve the Capacity Constrained Worker in Tempe Industry "Muchlar".
\end{abstract}

Keywords: Standard time, Capacity Constrained Worker, production target 


\section{PENDAHULUAN}

\section{Latar Belakang}

Sebuah industri didirikan dengan tujuan utama untuk memperoleh keuntungan. Salah satu sumber daya yang berperan penting dalam menentukan efisiensi ataupun efektifitas produksi adalah pekerja. Selain itu pekerja juga dapat menjadi kendala bagi sebuah industri yang apabila tidak diidentifikasi dapat menganggu tujuannya. Salah satu industri UMKM pangan yang terus berkembang di Indonesia adalah UMKM Tempe. Salah satu UMKM tempe yang cukup besar produksinya di Provinsi Daerah Istimewa Yogyakarta adalah tempe "Muchlar" di daerah Kasihan Bantul Yogyakarta. Tempe "Muchlar" merupakan industri pangan yang semua pekerjaannya dilakukan manual sehingga proses produksinya sangat tergantung kapasitas dari pekerja. Industri ini mempekerjakan sekitar 10 orang untuk bagian produksi sendiri sehingga kelancaran proses produksinya sangat tergantung kepada pekerjanya. Pekerjaan dalam proses pembuatan tempe ini membutuhkan keuletan dan tenaga yang tinggi karena pekerjaan yang dilakukan berulang-ulang dan dalam siklus yang pendek. Setiap harinya UMKM tempe muchlar mendapat permintaan tempe setengah jadi $\pm 4.000 \mathrm{~kg}$ dengan target $3.600 \mathrm{~kg}$ tempe setengah jadi. Target produksi tersebut akan diambil pukul 12.00 untuk dikemas dan sisanya diproduksi untuk dijual kepada pengecer. Permasalahan muncul karena setiap pukul 12.00 target produksi tidak dapat tercapai sehingga membuat jumlah tempe setengah jadi yang dikemas berkurang. Salah satu penyebab munculnya permasalahan ini karena perbedaan kapasitas setiap pekerja dalam menyelesaikan pekerjaannya. Perbedaan kapasitas setiap pekerja inilah yang dapat menjadi kendala kerja dalam menyelesaikan target produksi yang dikehendaki perusahaan. Dari perbedaan perbedaan kapasitas yang ada ini dapat menimbulkan munculnya kendala kerja atau constraint.

Salah satu konsep yang dapat digunakan untuk mengidentifikasi setiap kendala kerja yang ada dalam suatu industri adalah Theory of Constraint (ToC) Goldratt dan Cox (1992). ToC mennyatakan bahwa kinerja setiap perusahaan dibatasi oleh kendala-kendalanya. Jika hendak memperbaiki kinerjanya, suatu perusahaan harus mengidentifikasi kendalakendalanya, mengeksploitasi kendalanya dalam jangka pendek dan jangka panjang, kemudian menemukan cara untuk mengatasinya. Salah satu constraint yang terdapat dalam Theory of Constraint adalah adanya Capacity Constrained Resources (CCR). Menurut Radovilsky (1998) CCR dapat dibagi menjadi kendala mesin (Capacity Constrained Machine) dan pekerja yang menjadi constraint inilah yang disebut dengan Capacity Constrained Worker $(\mathrm{CCW})$. Capacity Constrained Worker sangat penting untuk diidentifikasi karena apabila tidak segera diidentifikasi dapat menyebabkan munculnya botlleneck.

\section{Rumusan Masalah}

Permasalahan utama yang diteliti dalam penelitian ini adalah bagaimana menganalisis permasalahan Capacity Constraint Worker tempe Muchlar yang dipengaruhi oleh faktor lingkungan dan fisiologis pekerja. Pemilihan permasalahan ini dikarenakan apabila Capacity Constraint Worker tidak segera diidentifikasi dapat menyebabkan terjadinya botlleneck yang dapat membuat waktu dan target produksi yang direncanakan tidak tercapai.

\section{Batasan Penelitian}

Batasan penelitian ini adalah setiap pekerja hanya melakukan pekerjaan pada satu stasiun kerja

\section{Tujuan Penelitian}

1. Mengidentifikasi kendala kapasitas pekerja berdasarkan pendekatan waktu baku, denyut jantung dan profile of mood states.

2. Dapat menentukan perbaikan yang tepat untuk meningkatkan kapasitas kerja pada stasiun yang mengalami constraint

\section{METODE PENELITIAN}

Metode penelitian terdiri atas:

\section{Obyek Penelitian}

Studi kasus penelitian dilakukan di UMKM Tempe Muchlar, Bantul Yogyakarta. Tempe Muchlar merupakan karakteristik UMKM yang mempunyai lingkungan kerja produksi yang fluktuatif dan besar pengaruhnya terhadap beban kerja.

\section{Sumber Data}

Sumber data terdiri atas data primer dan data sekunder sebagai berikut:

1. Data Primer

Data primer merupakan data yang diperoleh berdasarkan pengumpulan data secara langsung, baik secara pengamatan, wawancara, maupun penyebaran kuesioner. Data primer yang diperlukan dalam penelitian ini antara lain proses produksi, data denyut jantung pekerja, mood, waktu siklus pekerja dan faktor-faktor lain (seperti suhu, kebisingan dan pencahayaan). 


\section{Data Sekunder}

Data sekunder merupakan data yang diperoleh berdasarkan studi pustaka dan literatur yang berkaitan dengan penelitian dan perusahaan secara umum. Data sekunder yang diperlukan antara lain profil perusahaan, Allowance Factor, profil Pekerja dan jam kerja.

\section{Metode Pengumpulan Data}

Metode pengumpulan data terdiri atas:

1. Wawancara

Metode wawancara merupakan suatu metode pengumpulan data primer dengan mengajukan beberapa pertanyaan yang berkaitan dengan penelitian. Pertanyaan yang dapat dilontarkan antara lain proses produksinya, umur pekerja, nama pekerja, dan profil perusahaan.

2. Kuesioner

Metode kuesioner merupakan metode pengumpulan data dengan memberikan daftar pertanyaan kepada responden. Kuesioner yang dibagikan merupakan kuesioner tertutup yang memiliki lima pilihan jawaban, yaitu sangat tidak merasakan, tidak merasakan, netral, merasakan, dan sangat merasakan. Butir pertanyaan dalam kuesioner profile of mood states didasarkan dari kuesioner penelitian terdahulu, dan diubah sesuai dengan keadaan di lapangan.

3. Studi Pustaka

Studi pustaka dilakukan dengan mempelajari dan memahami pengumpulan data yang dapat digunakan sebagai alat untuk memecahkan permasalahan serta dapat dijadikan sebagai landasan teori yang dapat menbantu dalam memecahkan permasalahan tersebut. Studi pustaka dilakukan terhadap literatur - literatur yang berhubungan dengan penelitian dan penelitianpenelitian terdahulu.

\section{Tahapan Penelitian}

Tahapan penelitian dapat dijelaskan sebagai berikut:

1. Studi Pendahuluan

Studi pendahuluan merupakan observasi lapangan atau suatu pengamatan langsung pada obyek penelitian. Dengan studipendahuluan diharapkan dapatmemperoleh gambaran tentang masalah yang akan diteliti dan datadata yang akan diambil.

2. Pengukuran denyut jantung

Pengukuran tingkat denyut jantung dilakukan untuk memperoleh data tingkat denyut jantung pekerja yang akan dimanfaatkan untuk menganalisis dan menentukan Capacity Constrained Worker . Data denyut jantung didapatkan dengan mengukur denyut pekerja pada bagian produksi selama 12 hari dari pukul 07.00 - 14.00 WIB menggunakan alat Tensimeter (Tensoval) .
3. Penyebaran kuesioner Profile of Mood States (POMS) POMS adalah salah satu metodekuesioneryang bertujuan untuk menganalisa perasaan manusia (Mood). Mood dalam penelitian kali ini digunakan sebagai validasi dari denyut jantung dan waktu baku yang diperoleh. Dari kuesioner POMS yang dibagikan tersebut akan diperoleh data-data mood pekerja. Data-data tersebut kemudian dianalisa dengan menghitung Total Mood Disturbance (TMD) menggunakan persamaan (McNair dkk, 1992):

$T M D=T A+D+A H+F+C-V-F$

Dimana:

$T A=$ Tension-Anxiety

$D=$ Depresion-Dejection

AH $=$ Anger-Hostility

$F=$ Fatique

$C=$ Confusion

$V=$ Vigor

$F=$ Friendliness

Nilai TMD yang diperoleh tersebut kemudian digunakan untuk menentukan nilai mood efisiensi menggunakan persamaan (Ushada dkk, 2013):

Mood Efisiensi $=\left(\frac{\text { Awal-akhir }}{\text { Awal }}\right)$

Dimana yang dimaksud awal adalah TMD awal sebelum bekerja dan akhir adalah TMD akhir setelah bekerja (Mulyati dan Ushada, 2012).

4. Pengukuran lingkungan kerja (suhu, kebisingan dan pencahayaan)

Pengukuran ini dapat menjadi pertimbangan untuk mengetahui kondisi lingkungan bekerja para pekerja. Salah satu alat yang digunakan untuk mengukur faktorfaktor ini adalah Thermorecorder (EXTECH RH520A220). EXTECH adalah alat yang dapat mengukur suhu dan kelembapan ruang. Kebisingan dan cahaya dapat diukur menggunakan Multifunction Environmental meter.

5. Pengukuran waktu siklus

Pengukuran waktu siklus setiap stasiun kerja menggunakan stopwatch dengan metode pembacaan jam henti berdasarkan metode repetitive timing yaitu pembacaan jam henti dilakukan pada setiap akhir elemen (Wignjosoebroto, 2000). Data waktu yang diambil dari setiap elemen kerja adalah 30 data. Perhitungan waktu siklus rata-rata diperoleh dari rata-rata waktu untuk kejadian-kejadian yang berjalan normal. 
Besarnya waktu siklus dapat dihitung menggunakan rumus:

$$
\begin{array}{cl} 
& W_{s}=\frac{\sum_{i=1}^{n} X_{i}}{N} \\
\text { Dimana: } \quad W_{s} & =\text { Waktu siklus rata-rata } \\
\sum_{i=1}^{n} X_{i} & =\text { Jumlah waktu pengamatan setiap siklus } \\
N \quad & =\text { Jumlah pengamatan }
\end{array}
$$

6. Uji keseragaman dan kecukupan data

Uji keseragaman dilakukan secara manual dan kenormalan data dilakukan menggunakan software SPSS. Pengujian Kenormalan data dapat diambil berdasarkan pengambilan keputusan probabilitas nilai $H_{o} . H_{o}$ diterima apabila probabilitas $\geq 0,05$ yang artinya data berdistribusi normal dan $H_{o}$ ditolak jika probabilitas $<0,05$ yang artinya data tidak berdistribusi normal. Sementara uji keseragaman bertujuan untuk mengetahui apakah data seragam dan tidak melampaui batasnya dalam perubahan data. Setelah data seragam langkah selanjutnya adalah uji kecukupan data. Uji kecukupan data dapat menggunakan persamaan :

$$
N^{\prime}=\left[\frac{\frac{k}{s} \sqrt{N \sum_{i=1}^{n} x_{i}{ }^{2}-\left(\sum_{i=1}^{n} x_{i}\right)^{2}}}{\sum_{i=1}^{n} x_{i}}\right]^{2}
$$

Dimana:

$k=$ Tingkat keyakinan dan $s=$ Tingkat ketelitian

$N^{\prime}=$ Jumlah pengamatan yang seharusnya dilakukan

$N=$ Jumlah pengamatan yang sudah dilakukan

$X_{i}=$ Waktu pengamatan dari setiap stasiun kerja

Data dikatakan sudah mencukupi apabila $N$ ' lebih kecil sama dengan dari $N$, apabila data belum mencukupi atau $N$ ' masih lebih besar dari $N$ maka data harus ditambah.

7. Menghitung waktu baku

Untuk menentukan waktu baku harus digunakan Rating Factor dan Allowance. Untuk menentukannya dalam penelitian ini digunakan Rating Factor dan Allowance dari tabel Westinghouse dan Allowance factor (Meyers dan Stewart, 2002). Dari waktu siklus dan rating faktor kemudian dapat diperoleh waktu normal menggunakan persamaan (Barnes, 1980):

$W_{n}=W_{s} x(1+R F)$

Dimana:

$W_{n}$ : Waktu normal

RF : Rating Factor

Dari waktu normal ini kemudian dapat ditentukan waktu bakunya menggunakan persamaan:
$W_{b}=W_{n} x(1+A F)$

Dimana:

$W_{b}$ : waktu baku

AF : Allowance Factor

8. Penentuan Capacity Constrained Worker

Setelah ditentukan waktu baku dari setiap pekerja dalam menyelesaikan setiap elemen kerjanya dapat ditentukan pekerja yang berpotensi menjadi Capacity Constrained Worker berdasarkan waktu baku yang tinggi, denyut jantung yang tinggi dan Profile of Mood States. Penentuan ini juga dikonfirmasi dengan analisis keadaan lingkungan pekerja.

9. Analisis dan Pembahasan

Hasil yang diperoleh dari tahapan penelitian dianalisis dan dibahas dengan bantuan teori atau referensi yang ada. Selain itu dalam analisis dan pembahasan ini digunakan buffer management.

10. Penarikan Kesimpulan dan Saran

Dari hasil dan pembahasan yang telah dilakukan kemudian dapat ditarik kesimpulan yang menjawab tujuan dari penelitian ini. Sementara saran dapat dimasukkan untuk memberi masukan terhadap penelitian-penelitian selanjutnya.

\section{HASIL DAN PEMBAHASAN}

\section{Hasil Pengamatan dan Pengukuran}

1. Profil Pekerja

Pekerja bagian produksi tempe Muchlar berjumlah sepuluh orang dimana masing-masing pekerja bertanggung jawab pada 1 stasiun kerja. Selanjutnya untuk mempermudah pemahaman hasil dan pembahasan kesepuluh pekerja di disebut pekerja 1 sampai pekerja 10 sesuai penomeran pada tabel 1 dibawah ini.

Tabel 1. Profil pekerja berdasarkan aktivitasnya

\begin{tabular}{clcc}
\hline Pekerja & \multicolumn{1}{c}{ Aktivitas } & $\begin{array}{c}\text { Umur } \\
\text { (tahun) }\end{array}$ & $\begin{array}{c}\text { Lama bekerja } \\
\text { (tahun) }\end{array}$ \\
\hline 1 & Pengayakan & 34 & 10 \\
2 & Pencucian Kedelai & 30 & 6 \\
3 & Perendaman I & 31 & 6 \\
4 & Perebusan I & 27 & 4 \\
5 & Penggilingan & 30 & 7 \\
6 & Pemisahan Kulit & 28 & 3 \\
7 & Perebusan II & 37 & 13 \\
8 & Perendaman II & 49 & 19 \\
9 & Peragian & 29 & 5 \\
10 & Pengemasan & 27 & 4 \\
\hline
\end{tabular}


2. Penentuan Waktu Baku

Pengukuran pertama yang dilakukan adalah pengukuran waktu baku menggunakan metode studi gerak dan waktu. Untuk menentukan waktu baku menggunakan metode ini terlebih dahulu harus ditentukan waktu siklus dan normal. Tabel 2 merupakan data hasil perhitungan waktu siklus, waktu normal dan waktu baku

Tabel 2. Waktu baku

\begin{tabular}{clll}
\hline Aktivitas & Waktu siklus & Waktu normal & Waktu baku \\
\hline 1 & 16,47 & 18,46 & 23,62 \\
2 & 49,64 & 53,61 & 69,97 \\
3 & 10,69 & 11,66 & 18,01 \\
4 & 6,04 & 5,98 & 9,03 \\
5 & 12,72 & 13,36 & 20,04 \\
6 & 135,99 & 155,04 & 236,72 \\
7 & 58,87 & 60,64 & 89,75 \\
8 & 31,82 & 32,77 & 48,83 \\
9 & 31,86 & 36,01 & 50,59 \\
10 & 110,85 & 127,72 & 156,83 \\
\hline
\end{tabular}

3. Denyut Jantung

Denyut jantung merupakan salah satu faktor fisiologis yang dapat digunakan untuk menentukan berat atau ringannya beban yang harus dilakukan oleh seorang pekerja. Pengukuran denyut jantung pada pekerja tempe ini dilakukan setiap 1 jam sekali dari pukul 07.0014.00 WIB. Pengukuran denyut jantung juga dilakukan sebelum bekerja, dan setelah selesai bekerja sampai denyut jantung kembali seperti denyut jantung sebelum bekerja. Rata-rata hasil pengukuran denyut jantung 10 pekerja ditunjukkan dalam gambar 1 .

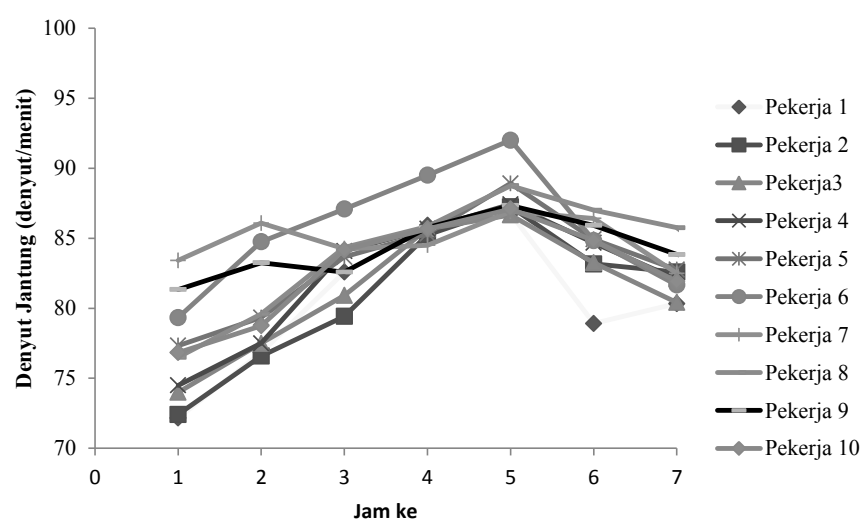

Gambar 1. Denyut jantung ke 10 pekerja berdasarkan aktivitasnya

\section{Profile of Mood States}

Mood adalah gambaran perasaan seorang individu yang sangat dipengaruhi lingkungan, sistem dan faktor eksternal (Hansen dkk., 2001). Semakin bagus tidaknya mood seorang pekerja tentu saja akan mempengaruhi kemampuan pekerja dalam menyelesaikan pekerjaannya. Salah satu alat yang dapat digunakan untuk mengukur nilai mood adalah kuesioner Profil of Moods States (POMS). Setelah semua data kuesioner POMS diperoleh , data tesebut diolah untuk memperoleh nilai Total Mood Disturbance (TMD). Dari nilai TMD tersebutlah kemudian baru dapat dianalisis kuesioner POMS. Semakin tinggi nilai TMD nya berarti menunjukkan mood semakin tidak baik. Nilai rata-rata TMD setiap pekerja selama 12 hari dapat dilihat pada gambar 2 :

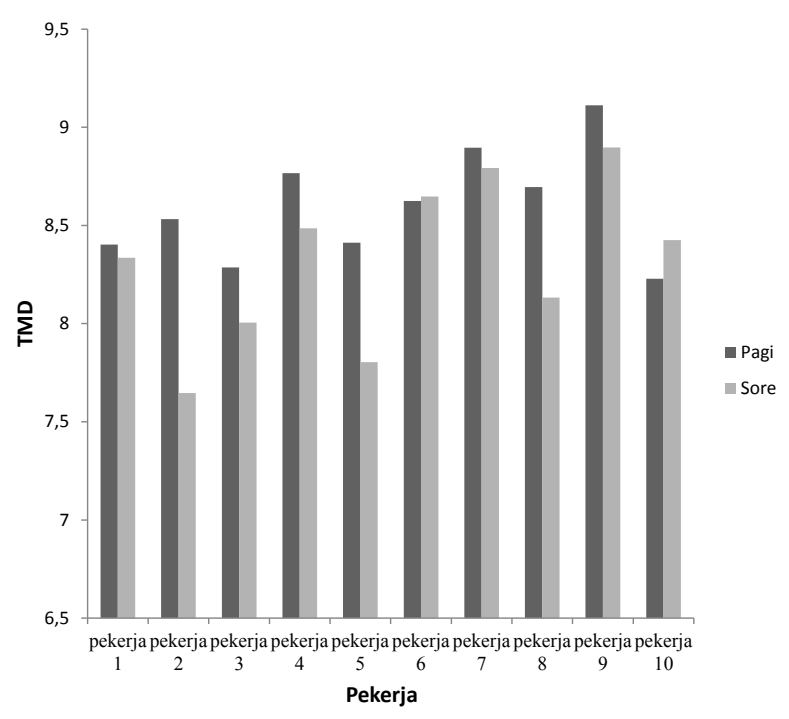

Gambar 2. Nilai rata-rata TMD pekerja berdasarkan aktivitasnya

\section{PEMBAHASAN}

\section{Penentuan Capacity Constrained Worker}

\section{Identifikasi Capacity Constrained Worker}

Apabila CCW tidak segera diidentifikasi dan dikelola dengan baik dapat menyebabkan botleneck yang dapat mengganggu kelancaran produksi. Dalam ToC sendiri untuk mengidentifikasi constraint dapat dibagi menjadi 3 bagian yaitu: Fisik (Dengan kapasitas sumberdaya yang kurang dari permintaan), Pasar ( permintaan kurang dari kapasitas sumber daya) dan Kebijakan (Peraturan formal atau tidak formal yang mengatur batas kapasitas produksi suatu system) (Watson,2007). Dalam penelitian kali ini constraint yang akan ditentukan adalah constraint fisik yaitu pekerja. Untuk menentukan constraint adalah dengan melihat kapasitas pekerja yang tidak dapat memenuhi atau kurang dari permintaan yang diberikan dan beban kerja pekerja. Kapasitas pekerja dapat ditunjukkan dengan waktu baku yang diperoleh dari studi gerak. 
Tabel 3. Faktor-faktor yang mempengaruhi Capacity Constrained Worker (CCW)

\begin{tabular}{|c|c|c|c|c|c|c|}
\hline \multirow[b]{2}{*}{ No } & \multirow[b]{2}{*}{ Aktivitas } & \multirow{2}{*}{$\begin{array}{c}\text { Faktor } \\
\text { Denyut jantung } \\
\text { (Denyut/ menit) }\end{array}$} & \multirow[b]{2}{*}{$\begin{array}{l}\text { Waktu Baku } \\
\text { (det/kg) }\end{array}$} & \multicolumn{3}{|c|}{ Lingkungan } \\
\hline & & & & Suhu $\left({ }^{\circ} \mathrm{C}\right)$ & Kebisingan (db) & Pencahayaan (lux) \\
\hline 1 & Pengayakan & 80 & 1,6 & $29,5 \pm 1,7$ & $65,8 \pm 3,4$ & $231,6 \pm 6$ \\
\hline 2 & Pencucian & 80,7 & 4,4 & $29,5 \pm 1,7$ & $65,8 \pm 3,4$ & $231,6 \pm 6$ \\
\hline 3 & Perendaman & 80,6 & 1 & $34,4 \pm 1,1$ & $85,8 \pm 1,6$ & $339,7 \pm 5,2$ \\
\hline 4 & Perebusan 1 & 81,5 & 1,2 & $34,4 \pm 1,1$ & $85,8 \pm 1,6$ & $339,7 \pm 5,2$ \\
\hline 5 & Penggilingan & 82,9 & 3,3 & $34,4 \pm 1,1$ & $85,8 \pm 1,6$ & $339,7 \pm 5,2$ \\
\hline 6 & Pemisahan kulit & 85,2 & 5,6 & $34,4 \pm 1,1$ & $85,8 \pm 1,6$ & $339,7 \pm 5,2$ \\
\hline 7 & Perendaman 2 & 85,1 & 1,5 & $34,4 \pm 1,1$ & $85,8 \pm 1,6$ & $339,7 \pm 5,2$ \\
\hline 8 & Perebusan 2 & 83,7 & 0,8 & $34,4 \pm 1,1$ & $85,8 \pm 1,6$ & $339,7 \pm 5,2$ \\
\hline 9 & Pendinginan & 84,1 & 3,6 & $32,4 \pm 0,6$ & $73,2 \pm 1,1$ & $189,4 \pm 4,2$ \\
\hline 10 & Pengemasan & 83,2 & 3,1 & $32,4 \pm 0,6$ & $73,2 \pm 1,1$ & $189,4 \pm 4,2$ \\
\hline
\end{tabular}

Kapasitas pekerja sendiri dipengaruhi oleh beberapa faktor seperti lingkungan, fisiologis dan psikologis pekerja. Dalam penelitian kali ini untuk dapat mengidentifikasi potensi terjadinya Capacity Constrained Worker dapat melihat denyut jantung serta keadaan lingkungan yang mempengaruhinya. Tabel 3 diatas ini menunjukkan faktorfaktor yang mempengaruhi CCW sehingga dapat digunakan untuk identifikasi CCW.

Dengan melihat Tabel 3 dapat dilihat bahwa stasiun kerja yang memilik potensi menjadi Capacity Constrained Worker adalah stasiun pemisahan kulit. Hal tersebut didukung dengan beberapa faktor yang mempengaruhinya seperti kapasitas pekerja untuk menyelesaikan pekerjaannya paling lama dari pada stasiun-stasiun lain yaitu 5,629 detik/ $\mathrm{kg}$. Selain itu dengan melihat mood efisiensinya yang negatif yaitu - 0,003 menunjukkan terjadinya penurunan mood ketika bekerja. Penurunan mood ini dapat menyebabkan pekerja tidak optimal dalam bekerja sehingga mempengaruhi produktivitasnya. Denyut jantungnya yang paling tinggi dengan rata-rata 85,22 dapat menunjukkan beban kerjanya lebih tinggi daripada pekerja lain. Hal tersebut dapat menjadi potensi paling besar terjadinya Capacity Constrained Worker. Hal tersebut didukung dengan keadaan lingkungannya yang kurang kondusif dengan suhu yang sangat panas yaitu 34,37 $\pm 1,12^{\circ} \mathrm{C}$ dan tingkat kebisingannya yang sangat tinggi yaitu $85,84 \pm 1,59 \mathrm{db}$.

Potensi CCW yang terjadi pada pemisahan kulit salah satunya disebabkan karena kapasitas pekerja yang paling rendah. Untuk membuktikan hal tersebut dapat dilihat dengan membandingkan antara kapasitas pekerja dengan tingkat permintaan yang dibebankan kepadanya. Tempe Muchlar rata-rata setiap harinya menerima permintaan kurang lebih $4.000 \mathrm{~kg}$ tempe setengah jadi dengan target $3.600 \mathrm{~kg}$ yang akan diambil setiap pukul 12.00 untuk dikemas dan sisanya diproduksi setelah pukul 12.30 untuk dijual kepada pengecer. Pekerja mempunyai waktu kurang lebih 5 jam untuk memenuhi target sebesar $3.600 \mathrm{~kg}$ tersebut. Sehingga dari kapasitas pekerja yang diperoleh dari waktu baku pekerja dapat ditentukan pencapaiannya apakah telah memenuhi permintaan atau belum. Tabel 4 menunjukkan jumlah output yang dihasilkan setiap stasiun kerja untuk memenuhi tercapainya target $3.600 \mathrm{~kg}$ dalam 5 jam.

Dari Tabel 4 dapat dilihat bahwa pekerja 6 pada stasiun pemisahan kulit tidak dapat mencapai target sesuai dengan permintaan. Hal ini dapat mempengaruhi tingkat keuntungan perusahan yang akan diperoleh. Dari hasil inilah yang menunjukkan bahwa stasiun pemisahan kulit merupakan Capacity Constrained worker yang dapat menjadi kendala bagi perusahaan untuk mancapai tujuannya dalam hal ini tingkat keuntungan yang lebih tinggi.

Tabel 4. Pencapaian produksi setiap aktivitas

\begin{tabular}{cccc}
\hline Pekerja & $\begin{array}{c}\text { Kapasitas } \\
(\mathrm{kg} / \mathrm{menit})\end{array}$ & $\begin{array}{c}\text { Capaian produksi } \\
\text { dalam 5 jam }(\mathrm{kg})\end{array}$ & Keterangan \\
\hline 1 & 38,2 & 11.460 & Tercapai \\
2 & 13,64 & 4.092 & Tercapai \\
3 & 58,06 & 17.418 & Tercapai \\
4 & 49,8 & 14.940 & Tercapai \\
5 & 18,2 & 5.460 & Tercapai \\
6 & 10,65 & 3.200 & Tidak tercapai \\
7 & 40,11 & 12.033 & Tercapai \\
8 & 73,7 & 22.110 & Tercapai \\
9 & 16,56 & 4.968 & Tercapai \\
10 & 19,13 & 5.739 & Tercapai \\
\hline
\end{tabular}




\section{Perbaikan yang dapat Dilakukan}

Salah satu penyebab beban kerja pekerja pemisahan kulit lebih tinggi daripada pekerja lain adalah keadaan lingkungannya yang kurang kondusif dengan suhu mencapai $34,37 \pm 1,12^{\circ} \mathrm{C}$ dan kebisingan 85,84 $\pm 1,59 \mathrm{db}$. Dengan suhu dan kebisingan tersebut dapat membuat nilai allowance faktor untuk pekerja menjadi tinggi. Nilai allowance untuk pekerja pemisahan kulit paling tinggi disebabkan oleh temperature yang tinggi dengan nilai kelonggaran mencapai $20 \%$. Dengan total Allowance Factor yang mencapai 53 \% tersebut waktu baku yang diperoleh pada stasiun pemisahan kulit menjadi $5,629 \mathrm{detik} / \mathrm{kg}$ dari waktu normal sebesar 3,71 detik/kg. Oleh karena itulah perlu dilakukan perbaikan khususnya untuk mengurangi suhu dan tingkat kebisingan yang terjadi. Apabila suhu dapat diturunkan dari kategori tinggi ke normal dan efek tingkat kebisingan dapat dikurangi maka nilai kelonggaran untuk temperature dapat turun dari $20 \%$ menjadi $5 \%$ dan keadaan lingkungan dapat turun dari $5 \%$ menjadi $0 \%$. Dengan demikian, nilai Allowance factor untuk pemisahan kulit dapat berubah menjadi :

Tabel 5. Allowance Factor pemisahan kulit setelah simulasi perbaikan

\begin{tabular}{lllc}
\hline Stasiun & \multicolumn{1}{c}{ Faktor } & Keterangan & Kelonggaran \\
\hline \multirow{6}{*}{$\begin{array}{l}\text { Tenaga yang } \\
\text { dikeluarkan }\end{array}$} & Sedang & $15 \%$ \\
& Sikap kerja & Membungkuk & $5 \%$ \\
& Gerakan kerja & Terbatas & $2,5 \%$ \\
Pemisahan & Kelelahan mata & Cahaya baik & $0,00 \%$ \\
& Temperatur & Normal & $5 \%$ \\
& Keadaan atmosfer & Cukup & $5 \%$ \\
& Keadaan lingkungan & Baik & $0 \%$ \\
& Jenis kelamin & Pria & $2,5 \%$ \\
\cline { 2 - 4 } & & Jumlah & $35 \%$ \\
\hline
\end{tabular}

Dengan perbaikan yang dilakukan total Allowance faktor pekerja pemisahan kulit dapat turun dari $53 \%$ menjadi $35 \%$. Dengan perubahan tersebut maka waktu baku dan kapasitas pekerja pada pemisahan kulit dapat berubah menjadi :

$$
\begin{aligned}
W_{b} & =W_{n} \times(1+A F) \\
& =3,71 \times(1+0,35) \\
& =5,00 \mathrm{detik} / \mathrm{kg}
\end{aligned}
$$

Dengan waktu baku pekerja 5 detik/kg maka kapasitas pekerja dapat naik menjadi $12 \mathrm{~kg} /$ menit. Dengan kapasitas tersebut pekerja pemisahan kulit dalam 5 jam dapat menghasilkan tepat $3.600 \mathrm{~kg}$, sehingga tempe setengah jadi tersebut dapat terkirim tepat waktu pukul 12.00. Perbaikan yang dapat dilakukan antara lain dengan menyediakan alat pelindung pendengaran sehinga pengaruh bising dapat dikurangi dan membuat sekat antara pemisahan kulit dengan ruang kompor sehingga suhu panas dapat dikurangi.

\section{Time Buffer}

Salah satu cara untuk memastikan hal tersebut adalah dengan memberikan time buffer pada stasiun-stasiun kerja (Duclos dan Spencer, 1995). Time buffer diletakkan sebelum stasiun constraint dengan maksud untuk memberikan waktu kepada stasiun constrain agar terhindar dari fluktuasi atau gangguan yang terjadi. Salah satu cara untuk menentukan besarnya time buffer adalah dengan memberikan setengah dari waktu proses stasiun constraint (Umble dan Srikanth, 1996). Waktu yang digunakan adalah waktu untuk stasiun constraint yang telah diperbaiki yaitu 5 detik $/ \mathrm{kg}$, sehingga besarnya time buffer yang diberikan adalah 2,5 detik/ $\mathrm{kg}$. Setelah besarnya time buffer dapat ditentukan, kemudian dapat ditentukan status dari buffer yang diberikan menggunakan teknik buffer management. Dari teknik ini, status buffer dapat dibagi menjadi 3, untuk green (buffer status lebih dari 67\%) memiliki arti bahwa telah tersedia banyak waktu untuk memenuhi order. Untuk yellow (buffer status diantara 33\% $67 \%$ ) memiliki arti bahwa waktu yang tersedia cukup riskan untuk memenuhi order tepat waktu. Untuk red (buffer status kurang dari 33\%), waktu yang tersedia untuk memenuhi order tepat waktu sangat kecil sehingga perlu dilakukan perbaikan secara besar-besaran. Untuk menentukan besarnya buffer status ini dapat digunakan persamaan:

Buffer status $(\%)$ = Waktu yang disediakan/Waktu buffer produksi ......7)

Waktu yang disediakan untuk kasus tempe muchlar adalah 5 jam, karena tempe setengah jadi sebanyak 3.600 $\mathrm{kg}$ akan diambil pada pukul 12.00 dan jam kerjanya dimulai pukul 07.00 sehingga ada waktu 5 jam untuk menyelesaikan target. Time buffer produksi diperoleh dengan menjumlahkan waktu baku pekerja setiap stasiun dengan time buffer yang diberikan yaitu 2,5 detik/ $\mathrm{kg}$. Tabel 6 menunjukkan hasil perhitungan buffer status setiap stasiun kerja. Dari buffer status yang diperoleh setelah perbaikan dapat dilihat bahwa setiap stasiun termasuk kategori green yang berarti walaupun ada gangguan order yang dipesan tetap dapat datang tepat waktu. Hal tersebut dapat menunjukkan bahwa sudah tidak terdapat Capacity Constrained Worker yang mempengaruhi target produksi tidak tercapai. 
Tabel 6. Buffer status setiap stasiun kerja

\begin{tabular}{clc}
\hline No & Stasiun kerja & Buffer status (\%) \\
\hline 1 & Pengayakan & 221 \\
2 & Pencucian & 129 \\
3 & Perendaman 1 & 141 \\
4 & Perebusan 1 & 86,35 \\
5 & Penggilingan & 135,64 \\
6 & Pemisahan Kulit & 67,7 \\
7 & Perendaman 2 & 125 \\
8 & Perebusan 2 & 151 \\
9 & Pendinginan & 81,7 \\
10 & Pengemasan & 88,7 \\
\hline
\end{tabular}

\section{KESIMPULAN}

1. Capacity Constrained Worker terjadi pada stasiun pemisahan kulit dengan waktu baku terlama 5, 63 detik/ $\mathrm{kg}$ dan denyut jantung tertinggi, sehingga membuat target produksi tempe setengah jadi sejumlah $3.600 \mathrm{~kg}$ pada pukul 12.00 tidak tercapai.

2. Dengan perbaikan yang dilakukan yaitu menurunkan suhu ruangan dari tinggi ke normal waktu baku pekerja dapat meningkat menjadi $5 \mathrm{detik} / \mathrm{kg}$ dan target produksi dapat tercapai serta meningkatkan pendapatan. Perbaikan dengan menerapkan buffer management dapat mengurangi stasiun kerja yang menjadi constraint.

\section{UCAPAN TERIMA KASIH}

Penulis menghaturkan ucapan terima kasih kepada Hitachi Scholarship Foundation untuk dana penelitian Hitachi Graduate Support Program 2011-2013 dan kepada DIKTI melalui Hibah Kerjasama Internasional dan Publikasi Internasional 2014 untuk keberlanjutan penelitian ini. Penelitian ini merupakan bagian dari RECAT (Research Collaboration in Agroindustrial Technology) kerjasama antara Jurusan Teknologi Industri Pertanian, Fakultas Teknologi Pertanian, Universitas Gadjah Mada dibawah koordinasi Dr. Mirwan Ushada dan Laboratory of Bioproduction Engineering, Department of Mechanical Engineering, Osaka Prefecture University, Jepang dibawah koordinasi Professor Dr. Haruhiko Murase

\section{DAFTAR PUSTAKA}

Barnes, R.M. (1980). Motion and Time Study, Design and Measurement of work. $7^{\text {th }}$ edition. John Wiley and Sons, Singapore.

Duclos, L.K. dan Spencer, M.S. (1995). The impact of a constraint buffer in a flow shop. Internasional Journal of Production Economics 42: 175-185.

Goldratt, E.M. dan Cox, J. (1992). The Goal, A Process of Ongoing Improvement, Rev. $2^{\text {nd }}$ edition. Nort River Press, Croton-Hudson, NY.

Hansen, C.J., Stevens, Larry, C. dan Coast, R. (2001). Exercise duration and mood state: how much is enough to feel better. Health Psychology 20(4): 267-275.

McNair, D.M., Lorr, M. dan Droppleman, L.F. (1992). Manual for the profile of mood states (Rev. ed.) San Diego, CA: Educational and Industrial Testing Service.

Meyers, F.E dan Stewart, J. (2002). Motion and Time Study For Lean Manufacturing. $3^{\text {th }}$ edition. Pearson education, New Jersey.

Mulyati, T,G. dan Ushada, M. (2012). Aplikasi ergonomi dan kansei engineering pada proses produksi "snack GNP". Seminar Nasional Ergonomi, ISBN -978-602-17085$0-7$.

Radovilsky, Z.D. (1998). A quantitative approach to estimate the size of the time buffer in the theory of constraint. International Journal of production Economics 55: 113-119.

Ushada, M., Mulyati, G., Guritno, A. dan Murase, H. (2013). Combining drum-buffer-rope Algorithm and Kansei engineering to control capacity constrained worker in a bioproduction system. International Federation of Automatic Control (IFAC) Biorobotics III Workshop in Osaka-Japan, 2013.

Watson, K.J., Blackstone, J.H. dan Stanley, C.G. (2007). The evolution of a management philosophy: The theory of constraints. Journal of Operations Management 25: 387-402.

Wignjosoebroto, S. (2000). Ergonomi, Studi Gerak dan Waktu. Penerbit Guna Widya. Surabaya. 